- Regina Paolucci El Dib
- Álvaro Nagib Atallah
- Régis Bruni Andriolo
- Bernardo Garcia de Oliveira Soares
- Jos Verbeek

ABSTRACT

CONTEXT AND OBJECTIVE: Noise-induced hearing loss can only be prevented by eliminating or lowering noise exposure levels. When the source of the noise cannot be eliminated, workers have to rely on hearing protection equipment. The aim here was to summarize the evidence for the effectiveness of interventions to enhance the wearing of hearing protection among workers exposed to noise in the workplace.

DATA SOURCE: Studies with random assignment were identified by an electronic search of the medical literature up to 2005. Data were double-entered into the Review Manager software, version 4.2.5

DATA SYNTHESIS: Two studies were found. A computer-based intervention tailored to individual workers' risks and lasting 30 minutes was not found to be more effective than a video providing general information for workers. A second randomized controlled trial evaluated the effect of a four-year school-based hearing loss prevention program among schoolchildren working on their parents' farms. The intervention group was twice as likely to wear some kind of hearing protection as was the control group (which received only minimal intervention).

REVIEWERS' CONCLUSIONS: The limited evidence does not show whether tailored interventions are more or less effective than general interventions among workers, $80 \%$ of whom already use hearing protection. Long-lasting school-based interventions may increase the use of hearing protection substantially. Better interventions to enhance the use of hearing protection need to be developed and evaluated in order to increase the prevention of noise-induced hearing loss among workers.

KEY WORDS: Ear protective devices. Noise-induced hearing loss. Occupational noise. Review literature. Meta-analysis.

\title{
A systematic review of the interventions to promote the wearing of hearing protection
}

\author{
Discipline of Emergency Medicine, Brazilian Cochrane Center, \\ Universidade Federal de São Paulo (Unifesp), São Paulo, Brazil
}

NTRODUCTION

Noise-induced hearing loss is one of the most common occupational diseases and the second most common self-reported occupational illness or injury. The condition is permanent and irreversible. Furthermore, there is no effective treatment for permanent hearing loss resulting from excessive noise exposure. However, the condition can be prevented by preventive measures, and sets of such measures are usually combined into hearing loss prevention programs (also called hearing conservation programs). Personal protective measures (e.g. earplugs or earmuffs) always form one part of a hearing loss prevention program. ${ }^{1}$ Even though the efficacy of these measures for shielding the inner ear from noise has been proven in laboratory settings, their effectiveness for preventing hearing loss from accumulated noise exposure depends mainly on how regularly they are used by workers. Studies have shown that if workers do not wear hearing protection for $100 \%$ of the time, its effectiveness will quickly diminish. For example, wearing hearing protection for only $90 \%$ of the time will decrease effectiveness to less than one third. ${ }^{2}$ Educational or behavioral interventions to promote its use are therefore important preventive measures.

\section{PREVALENCE AND ETIOLGEY}

The risk of hearing loss due to noise exposure has long been recognized. Approximately 30 million workers in the United States alone are exposed to hazardous noise at work. ${ }^{3}$ Early damage is typically sustained in the basal turn of the cochlea and affects hearing in the frequency range from 3000 to $6000 \mathrm{Hertz}(\mathrm{Hz})$ (the frequency range of speech). One study calculated an annual worldwide incidence of noise-induced hearing loss of 1,628,000 cases. ${ }^{4}$ With a worldwide population of 6.525 billion this is equal to 25 per 100,000 per year. Long- term exposure to noise levels greater than 80 $\mathrm{dB}(\mathrm{A})$ (i.e. situations in which you have to raise your voice if you want to communicate with someone who is within a distance of one meter) carries an increased risk of hearing loss, which increases exponentially with the noise level. The risk of hearing impairment (average hearing loss $>35 \mathrm{~dB}(\mathrm{~A})$ at 1,2 and $3 \mathrm{kHz}$ ) at age 60 due to 40 years of exposure to noise levels of $100 \mathrm{~dB}(\mathrm{~A})$ has been estimated as $55 \% .^{5}$ Concurrent exposure to ototoxic substances, such as solvents and heavy metals, may increase the potential for damage from noise. ${ }^{6}$ Individuals' susceptibility to the adverse effects of noise exposure is highly variable and cannot be accurately predicted.

\section{PREVENTION}

Hearing loss prevention programs in industry have been widely advocated. Occupational health and safety legislation obliges employers to take preventive measures in most countries. ${ }^{1}$ These have proven to be effective to some extent in countries like Finland, where the incidence of cases of noise-induced hearing loss halved between 1987 and 2002. ${ }^{7}$ In the European Union and the United States, assessment of exposure to noise is obligatory, as is periodic screening of workers exposed to certain noise levels. Employers are also obliged to follow a "hierarchy of hazard controls". This is designed to eliminate hazards in the workplace in a particular order, by establishing controls at the source of the hazard (engineering or administrative) before using less reliable human controls (in this case the wearing of personal protective equipment). However, technical or economic reasons may mean that human controls are heavily relied upon. Indeed, a recent study has shown that personal protective equipment is still a widely used hazard control. ${ }^{8}$ From laboratory studies, it is known that this equipment (earplugs and 
earmuffs) is effective in reducing exposure to noise, although this effectiveness can lessen under field conditions.?

\section{HEARINE PROTECTION PROCRAME}

Studies in the United States indicate that there has been an increase in the use of hearing protection, but that there is still ample room for improvement. ${ }^{10}$ Several factors have been reported to influence the wearing of hearing protection, such as health beliefs, perceived risk, perceived likelihood of risk and comfort of wearing the device. ${ }^{2,11-13}$ Based on these models, several trials have been conducted to study the effectiveness of interventions to influence the wearing of hearing protection and decrease exposure. ${ }^{14-18}$ Until now, there has been no systematic review that summarized the results from these trials.

The aim here was to summarize the evidence for the effectiveness of interventions to enhance the wearing of hearing protection among workers exposed to noise in the workplace.

\section{MATERIALS AND METHOD}

\section{SELECTED STUDIES}

A literature search covering the period from January 1996 to June 2005 was conducted using the following databases: Medical Literature Analysis and Retrieval System Online (Medline), Excerpta Medica database (Embase), Literatura Latino-Americana e do Caribe em Ciências da Saúde (Lilacs), National Institute for Occupational Safety and Health (NIOSHTIC), International Occupational Safety and Health Information Centre (CISDOC), Cumulative Index to Nursing \& Allied Health (CINAHL) and Cochrane Ear, Nose and Throat Disorders Group Specialized Register, the Cochrane Central Register of Controlled Trials (CENTRAL, The Cochrane Library, Issue 2 2005). The following exhaustive list of synonyms for hearing protective devices was used: ear protective device, hearing protective device, hearing protector, hearing protection, ear muff, ear plug, ear defender, protective equipment, (noise, occupational). In addition, the references given in the selected papers were examined, irrespective of the publication year.

Approximately 1500 titles were requested. After the reading of all titles, the reviewers (Regina El Dib and Régis Andriolo) selected 150 potential full articles to be included in the review if they had a randomised design, if they were among noise-exposed $(>80 \mathrm{~dB}(\mathrm{~A}))$ workers or pupils, if there was some kind of intervention to promote the wearing of hearing protection (compared to another intervention or no intervention), and if the outcome measured was the amount of use of hearing protection or a proxy measure thereof. Of this total, 138 articles were excluded from the review because they were classified as case reports, narrative reviews or letters to editors. Thus, following this assessment of full articles, only 12 publications were considered for inclusion in this review. Six studies were then excluded because they did not meet the inclusion criteria of the review (retrospective studies or non-randomized studies): Davis and Sieber (2002), ${ }^{19}$ Ewigman et al. (1990), ${ }^{20}$ Roeser et al. (1983), ${ }^{21}$ Toivonen et al. (2002), ${ }^{22}$ Walker $(1972)^{23}$ and Williams (2004). ${ }^{24}$ A further three are awaiting assessment because of the poor quality of the reports (Lusk et al. 1999, ${ }^{14}$ Sadler and Montgomery $1982^{17}$ and Zohar et al.1980 ${ }^{18}$ ). Thus, only two studies (three publications) that met the minimum methodological requirements were included in this review (Knobloch and Broste $1998,{ }^{25}$ Lusk et al. $2003^{15}$ and Lusk et al. $2004^{16}$ ).

\section{METHODOLOEICAL QUALITY} ABBEBBMENT

In order to assess the methodological quality of the selected studies, a quality assessment list was developed (Appendix 1). The items incorporated are generally accepted methodological criteria. The methodological quality of the trials included in this review was measured using the criteria described in the Cochrane Handbook, ${ }^{26}$ since scales and checklists are not a reliable method for assessing the validity of a primary study. ${ }^{27}$

Two reviewers (Regina El Dib and Régis Andriolo) independently assessed the trial quality of each study, in accordance with this assessment list. Subsequently, disagreements between the examiners, which were small, were discussed to reach a consensus.

\section{STATIBTICAL PROCEDURE}

Using the available reported data, $2 \times 2$ tables were constructed to relate determinants to outcomes. In these studies, the outcomes assessed were the proportion of participants who were wearing hearing protection devices relative to the proportion in the control group; intention to use the devices; perceived benefits from using hearing protection; barriers to the use of hearing protection (self-reported use of hearing protection); and awareness of risk. Relative risk (RR) and weighted mean difference (WMD) were used to make estimates of the effects from the treatment in the included studies. Furthermore, the 95 per cent confidence intervals (CI) of these RR and WMD were calculated.
RESULTS

\section{QUALITY ABgEgBMENT}

Lusk et al. ${ }^{15}$ and Lusk et al. ${ }^{16}$ described their allocation method as "computer-generated". There was otherwise no mention of allocation concealment. These studies were therefore graded B (unclear) with regard to quality of allocation concealment. Knobloch and Broste ${ }^{25}$ made use of a method to avoid contamination of participants: randomization by clusters. With regard to allocation concealment and generation of allocation, Knobloch and Broste ${ }^{25}$ was graded $B$, because these details were not described in the paper. Randomization by clusters, as used by Knobloch and Broste, ${ }^{25}$ is thought to be the best way to circumvent the problem of "contamination" inherent to interventions of an institutional nature, in which participants randomized to distinct interventional approaches have the chance to exchange their experiences in a common occupational environment.

Detection bias was present in the Knobloch and Broste ${ }^{25}$ study, since the intervention and data collection were carried out by the researchers. Knobloch and Broste ${ }^{25}$ did not allow for the cluster effect, which could have been estimated by providing intracluster correlation coefficients. ${ }^{28}$ We corrected for the cluster effect by calculating a possible design effect. The intracluster correlation coefficient from other school-based interventions can be estimated as $0.006 .^{23}$ The mean cluster size was 22.1. The design effect $\left(1+(m-1)^{*} \mathrm{r}\right)$ is thus $1+(22.1-1)^{*} 0.006=1.1266$. We divided the number of events and the sample sizes by the design effect and entered them into RevMan.

In the Lusk et al. ${ }^{15}$ and Lusk et al. ${ }^{16}$ studies, a rigorous method of randomization was used, which was generated by computer and sealed at the time of allocation. Nonetheless, these studies present an indication of selection bias because the trialists did not use a cluster randomization process.

Contrary to what could be expected from the long-term study by Knobloch and Broste, ${ }^{25}$ only $6.4 \%$ of the total number of participants in the intervention group and $10.05 \%$ of the control group dropped out from the study. The low dropout rates give this study a low risk of bias. The Lusk et al. ${ }^{15}$ and Lusk et al. ${ }^{16}$ studies were considered to present a high risk of bias, because they did not meet the attrition criterion. The withdrawal rate within their relatively short study periods was $53.2 \%$.

\section{Proline}

The clinical and methodological diversity found in the included studies meant that it was not possible to combine studies in a 
meta-analysis. Therefore, we only performed representations of meta-analyses, as follows:

PARTICIPANTS WITH PERSONAL TAILORED INFORMATION VERSUS PARTICIPANTS WITH NON-TAILORED (GENERAL) INFORMATION VERSUS CONTROL (COMMERCIAL VIDEOTAPE) GROUP

Graph 1 shows a representation of a meta-analysis in relation to the outcome "Mean percentage of time actually using hearing protection device in required areas, over the preceding week and month". There was a statistically significant difference favoring the participants who received tailored information rather than non-tailored information in the Lusk et al. ${ }^{15}$ study, with a weighted mean difference (WMD) of $5.70 \%$ and $95 \%$ confidence interval (CI) of 1.79 to 9.61. Comparing the tailored information strategy versus control (commercial videotape), there was also a statistically significant difference favoring the participants who received the tailored intervention (WMD $6.40 \%$; 95\% CI: 2.42 to 10.38 ), as shown in Graph 2. Finally, there was no statistically significant difference between the non-tailored information group and the control group (WMD 0.70\%; 95\% CI: -3.63 to 5.03 ), as shown in Graph 3 .
BOLSTERS (MAILED FLYERS): ALL PARTICIPANTS WITH TAILIRED INFIRMATION VERSUS ALL PARTICIPANTS WITH NON-TAILORED INFORMATION

Graph 4 shows a representation of a meta-analysis in relation to the outcome "Mean percentage of time actually using hearing protection device in required areas, over the preceding week and month". There was a statistically significant difference favoring the participants with tailored information in the subgroup that received a booster after 30 days (WMD $-11.40 \%$; 95\% CI: -18.31 to -4.49 ; $\mathrm{p}=0.001)$. No difference was demonstrated between the tailored and non-tailored infor-

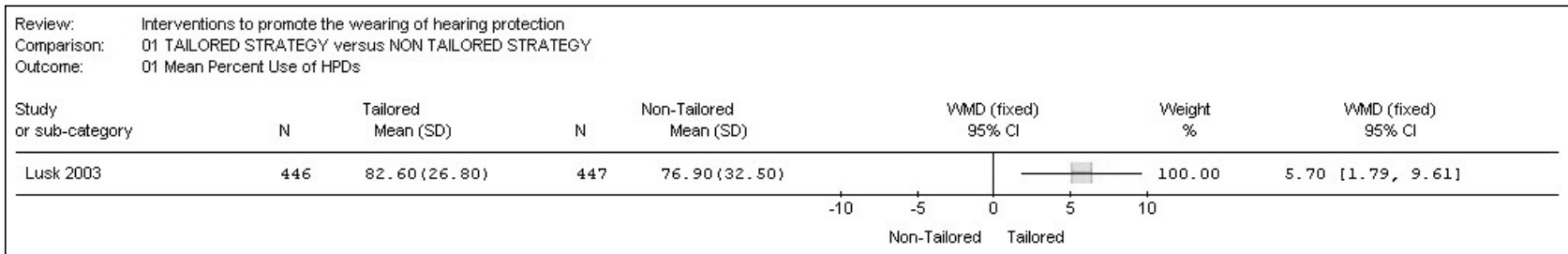

Graph 1. Participants with personal tailored information versus participants with non-tailored (general) information.

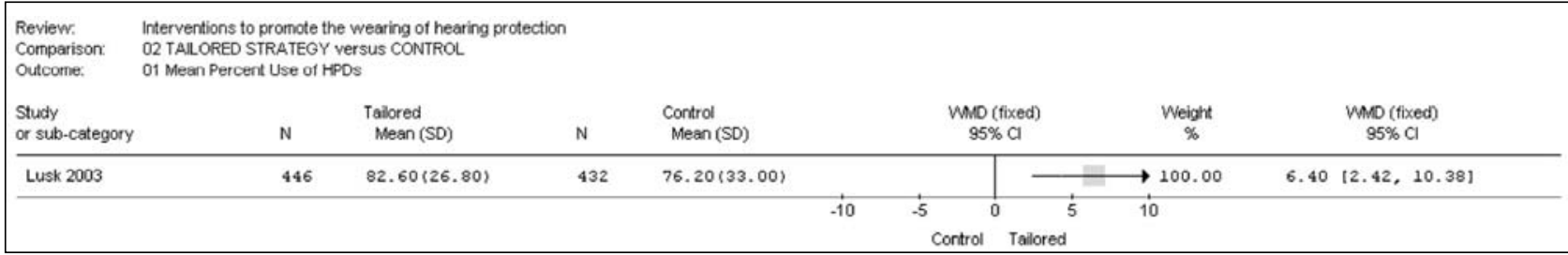

Graph 2. Participants with personal tailored information versus control (commercial videotape) group.

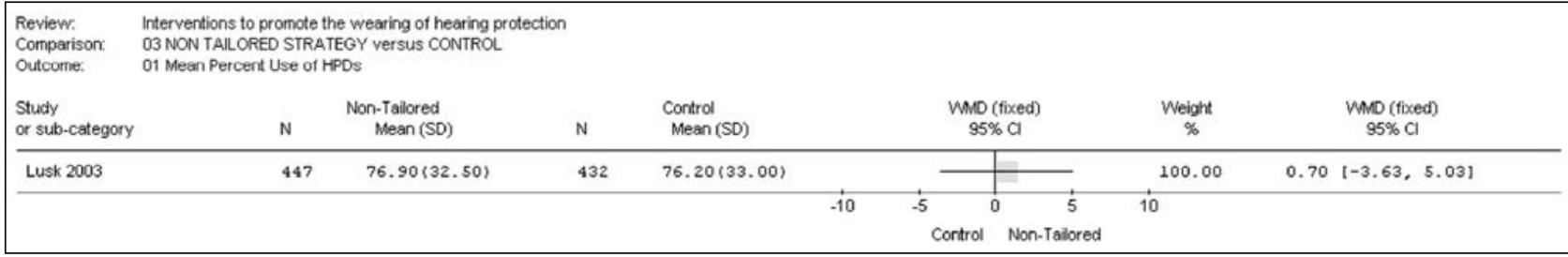

Graph 3. Participants with non-tailored (general) information versus control (commercial videotape) group.

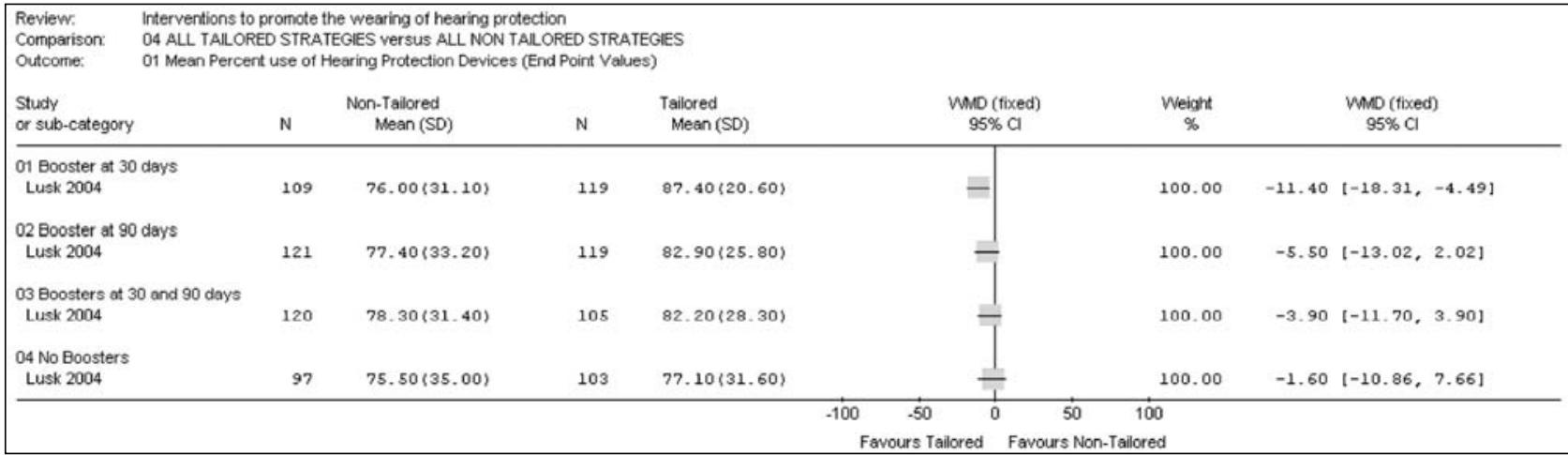

Graph 4. All participants with tailored information versus all participants with non-tailored information. 
mation groups in any of the other subgroups in Lusk et al. ${ }^{16}$ (booster after 90 days; booster after 30 and 90 days; no booster).

\section{BDOSTERS: ALL PARTICIPANTS WITH TAILORED INFORMATION VERSUS ALL CONTROL PARTICIPANTS}

In relation to the outcome "Mean percentage of time actually using hearing protection device in required areas, over the preceding week and month", two particular interventions seemed to favor the participants included in the tailored group over those included in the control group: booster after 30 days (WMD $-10.30 \%$; $95 \%$ CI: -18.09 to $-2.51 ; \mathrm{p}=0.01$ ) and boosters after 30 and 90 days (WMD
$-9.50 \%$; $95 \%$ CI: -17.86 to $-1.14 ; \mathrm{p}=0.03)$, as shown in Graph 5.

\section{MULTICOMPONENT EDUCATIONAL INTERVENTION VERSUS CONTROL (BASELINE HEARING TESTS AND} FOLLOW-UP TESTS)

Knobloch and Broste ${ }^{25}$ measured the percentage of students who used hearing protection devices "at least sometimes". After three years of the study, it was possible to detect a statistical difference favoring the participants in the intervention group over those in the control group (relative risk (RR) 0.42 ; $95 \%$ CI: 0.36 to $0.49 ; \mathrm{p}$ $<0.00001)$ (intention-to-treat analysis), as shown in Graph 6. The difference was maintained after four years (RR 0.51;95\% CI: 0.45 to $0.58 ; \mathrm{p}<0.00001$ ) (completer analysis), as shown in Graph 7. Results from a more rigorous analysis using the intention-to-treat approach revealed that the hearing conservation program trialed by these researchers was effective for both time points, i.e. after three and four years $(\mathrm{p}<0.0001)$. At the start of the study, only $23 \%$ of the intervention group and $24 \%$ of the control group wore hearing protection "at least sometimes". After three years, this had increased to $83 \%$ in the intervention group and $35 \%$ in the control group: an absolute difference of $48 \%$.

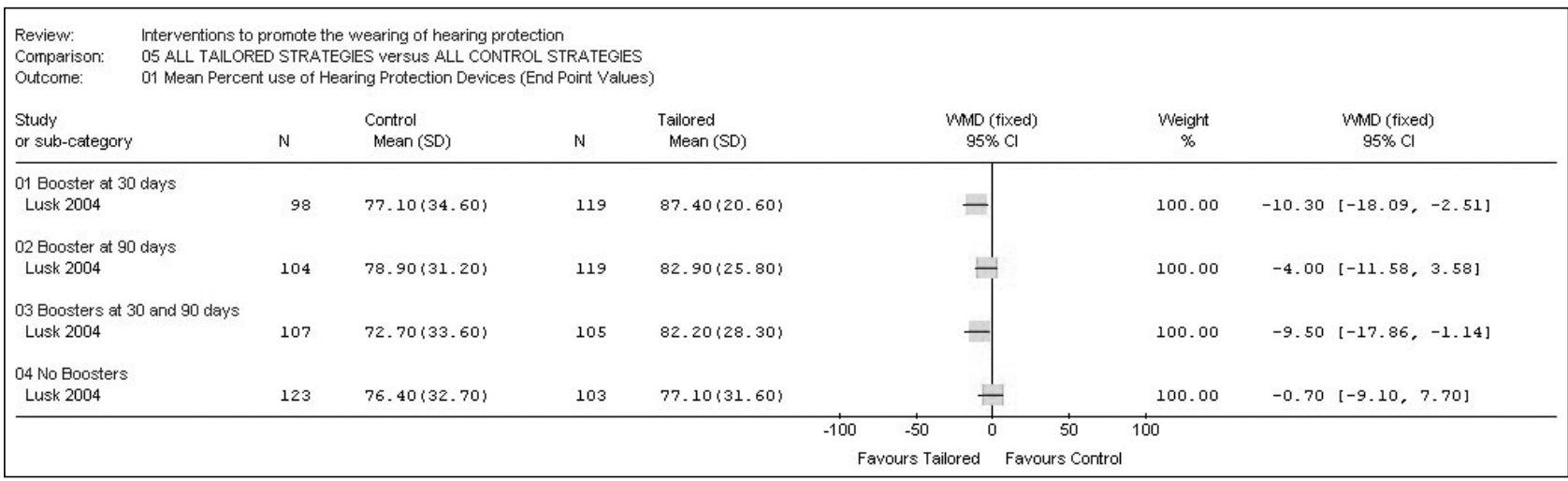

Graph 5. All participants with tailored information versus all control participants.

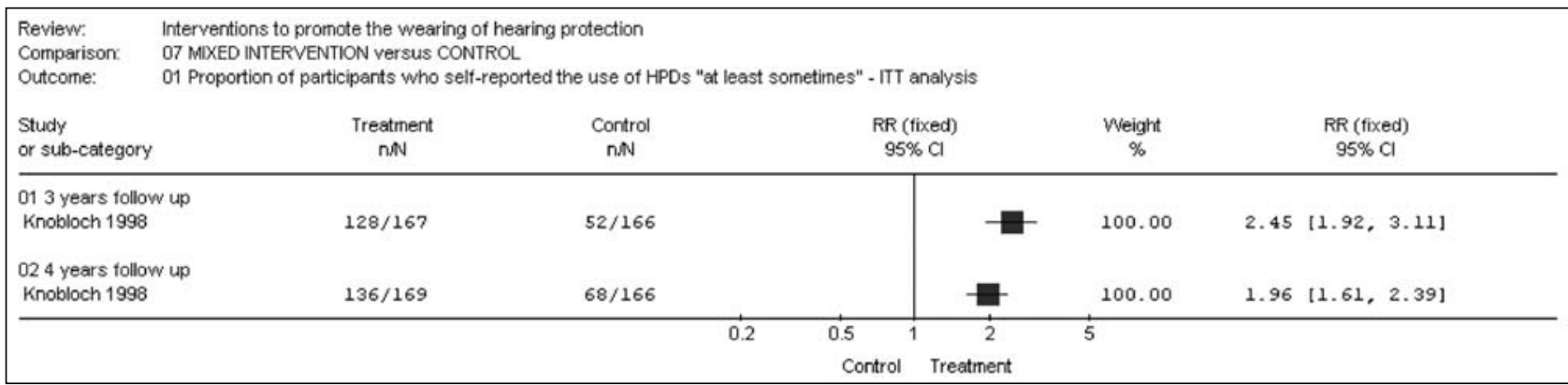

Graph 6. Multicomponent educational intervention versus control (intention-to-treat analysis).

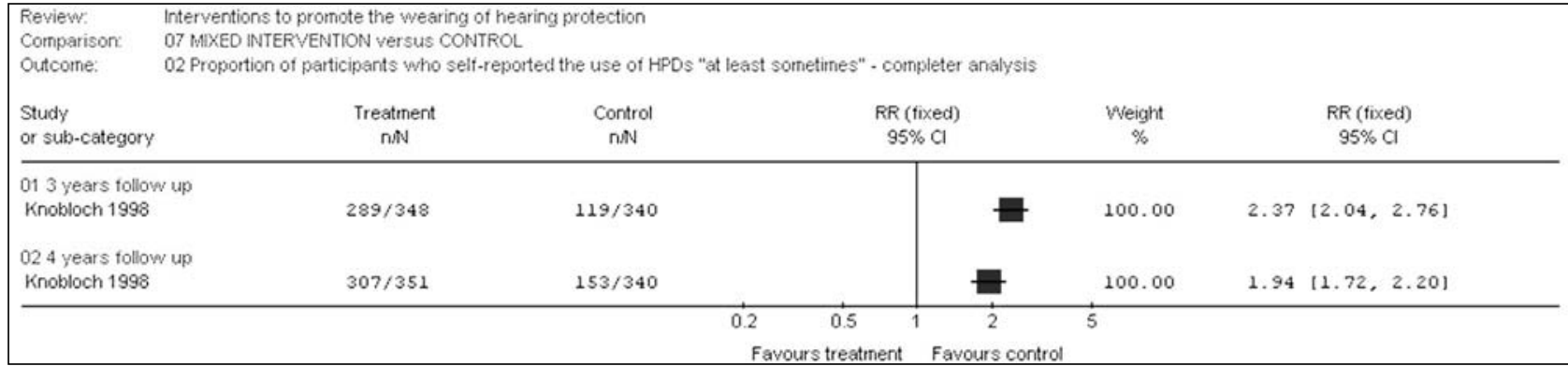

Graph 7. Multicomponent educational intervention versus control (completer analysis). 
DISCUSSIDN

This systematic review offers up-todate but limited evidence supported by randomized controlled trials, regarding the effectiveness of interventions to promote the wearing of hearing protection devices. Two of the studies ${ }^{15,16}$ included used the same participants but studied different interventions that both yielded a negative result among workers who had already reported substantial use of hearing protection. The methodological quality of the studies was reasonable, even though there was a substantial risk of attrition bias due to the loss from follow-up of half of the workers. This could imply that only those who were interested and motivated turned up for the post-intervention measurement. Moreover, it could mean that in a highly motivated group of workers it is difficult to increase the percentage of use of hearing protection. However, the risk of hearing loss increases exponentially with the amount of time for which protection is not worn. This means that there is a need to develop interventions that are capable of motivating workers in such a way that the percentage of use will also cover the remaining $20 \%$. Applying the intervention to the whole group, including those that already show perfect behavior in wearing hearing protection, does not seem to be very efficient. It might be worthwhile to explore further the possibilities of targeting the interventions at those that do not use hearing protection.

We found one study that applied the intervention to schoolchildren who were exposed to noise through their work at their parents' farms. ${ }^{25}$ The methodological quality was reasonable and the number of clusters and the number of participants were sufficient to demonstrate a significant difference. The outcome measurement used in that study (the percentage of participants who used hearing protection devices "at least sometimes") is difficult to interpret in the light of the axiom that hearing protection should be worn for $100 \%$ of the time a person is exposed to hazardous noise levels. However, it provides evidence that a school-based program maintained for several years can substantially increase the use of hearing protection, in comparison with a minimal intervention control group. In the United States, it has been suggested that there is substantial room for incorporating occupational health and safety information in vocational training schools..$^{29}$ Furthermore, in occupational health and school settings, cluster randomization seems to be a reasonable approach in designing randomized controlled trials. However, methods to allow for intracluster correlation must be used in the analysis of such studies.

There are many qualitative studies that have examined the reasons why workers do not use hearing protection. Comfort ${ }^{2,30-31}$ and the level of enforcement of the requirement to wear hearing protection ${ }^{11,13,30}$ have been reported as factors in not using hearing protection. Several models have been used to explain the variation in the use of hearing protection, such as the health promotion model and the protection-motivation theory. ${ }^{11,12}$ Researchers should make use of these studies to develop new interventions that might be more effective.

There are several studies showing that instructions on how to use earplugs are needed in order to properly insert them. In non-randomized studies that compared the noise attenuation of earplugs used with and without receiving instructions, a significant and important reduction in noise reduction between the groups was found. ${ }^{22,24}$

There is limited evidence that longterm school-based programs can effectively increase the use of hearing protection among students at vocational schools. To date, the limited evidence available does not demonstrate that the use of personalized information to motivate workers to use hearing protection is better than more general information. The limited evidence also does not show that the use of reminders after the intervention increases the use of hearing protection. It could be that this is due to a ceiling effect and only applies in situations in which the majority of workers already use hearing protection.

There are only a few good quality studies evaluating the effectiveness of interventions to promote the wearing of hearing protection devices. More randomized controlled trials are needed. To avoid the risk of contamination, cluster randomized trials are to be preferred. Proper adjustments should be made for the cluster effect and intracluster correlation coefficients should be reported. Future trials should have standardized outcome measurements such the endpoint proportion of participants who wear hearing protective devices in relation to the endpoint proportion in the control group, intention to use the devices, perceived benefits and barriers to the use of hearing protection (self-reported use of hearing protection). Dropouts and losses from follow up should be reported. 
Appendix 1. Data extraction form and methodological assessment list.

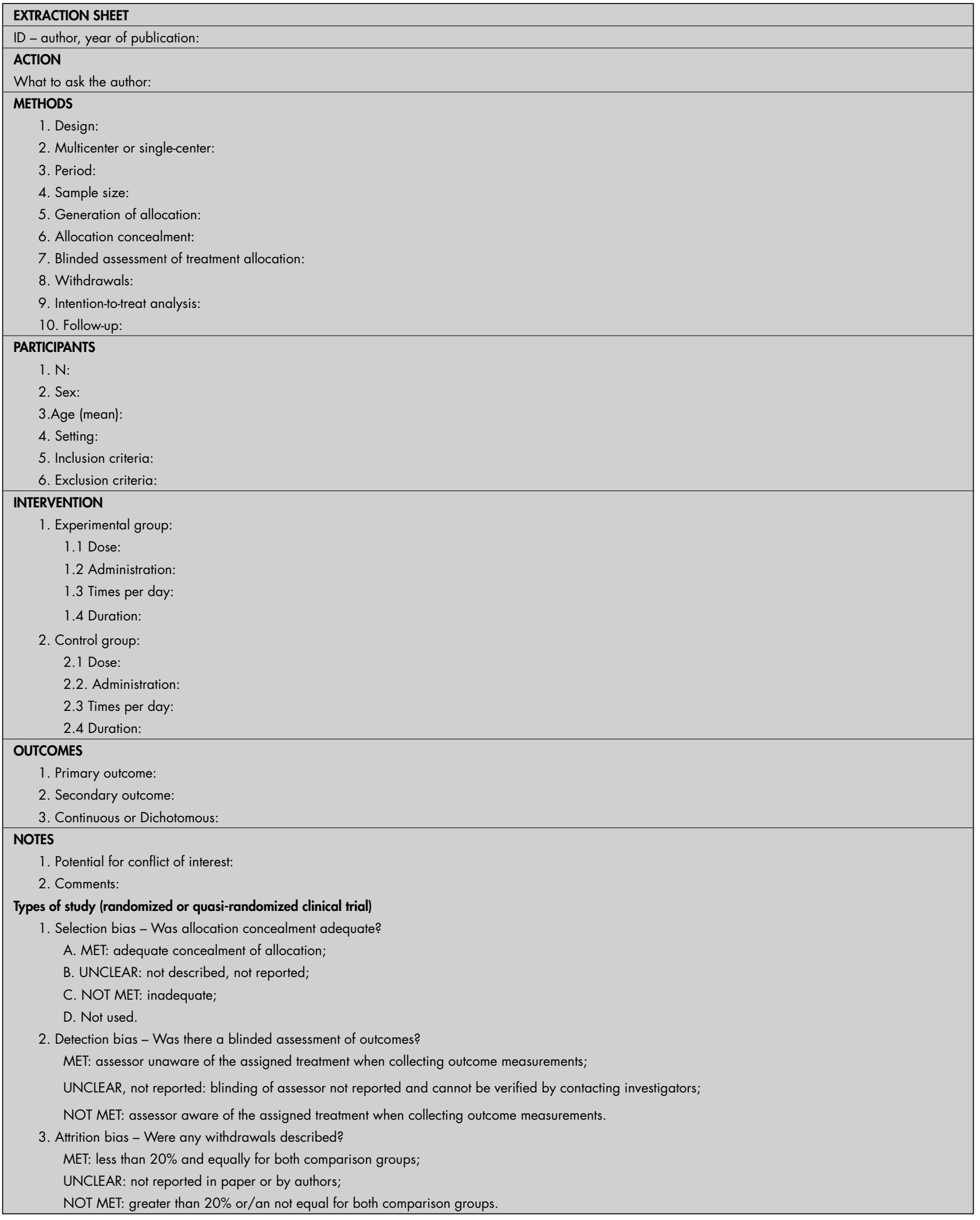


1. May JJ, Marvel M, Regan M, Marvel LH, Pratt DS. Noiseinduced hearing loss in randomly selected New York dairy farmers. Am J Ind Med. 1990;18(3):333-7.

2. Arezes PM, Miguel AS. Hearing protectors acceptability in noisy environments. Ann Occup Hyg. 2002;46(6):531-6.

3. World Health Organization. The world health report (Chapter 4). Selected occupational risks. Available from: http://www.who.int/whr/2002/chapter4/en/index8.html. Accessed in 2007 (Oct 10).

4. Leigh J, Macaskill P, Kuosma E, Mandryk J. Global burden of disease and injury due to occupational factors. Epidemiology. 1999;10(5):626-31.

5. Malchaire J, Piette A. A comprehensive strategy for the assessment of noise exposure and risk of hearing impairment. Ann Occup Hyg. 1997;41(4):467-84.

6. Morata TC, Dunn DE, Kretschmer LW, Lemasters GK, Keith RW. Effects of occupational exposure to organic solvents and noise on hearing. Scand J Work Environ Health. 1993;19(4):245-54.

7. Riihimäki H, Kurppa K, Karjalainen A, et al. Occupational diseases in Finland in 2002. New cases of occupational diseases reported to the Finnish Register of Occupational Diseases. Helsinki: Finnish Institute of Occupational Health; 2004. Available from: http://www.occuphealth.fi/NR/rdonlyres/ AF1A239E-A09D-47AB-9F69-16ED2B6D12ED/0/Occupational.pdf. Accessed in 2007 (Oct 10).

8. Roelofs CR, Barbeau EM, Ellenbecker MJ, Moure-Eraso R. Prevention strategies in industrial hygiene: a critical literature review. AIHA J (Fairfax, Va). 2003;64(1):62-7.

9. Giardino DA, Durkt G Jr. Evaluation of muff-type hearing protectors as used in a working environment. Am Ind Hyg Assoc J. 1996;57(3):264-71.

10. Davis RR, Sieber WK. Trends in hearing protector usage in American manufacturing from 1972 to 1989. Am Ind Hyg Assoc J. 1998;59(10):715-22.

11. Kerr MJ, Lusk SL, Ronis DL. Explaining Mexican American workers' hearing protection use with the health promotion model. Nurs Res. 2002;51(2):100-9.

12. Melamed S, Rabinowitz S, Feiner M, Weisberg E, Ribak J. Usefulness of the protection motivation theory in explaining hearing protection device use among male industrial workers. Health Psychol. 1996;15(3):209-15.
13. Patel DS, Witte K, Zuckerman C, et al. Understanding barriers to preventive health actions for occupationa noise-induced hearing loss. J Health Commun. 2001;6(2): $155-68$.

14. Lusk SL, Hong OS, Ronis DL, Eakin BL, Kerr MJ, Early MR. Effectiveness of an intervention to increase construction workers' use of hearing protection. Hum Factors. 1999;41(3):487-94.

15. Lusk SL, Ronis DL, Kazanis AS, Eakin BL, Hong O Raymond DM. Effectiveness of a tailored intervention to increase factory workers' use of hearing protection. Nurs Res. 2003;52(5):289-95.

16. Lusk LS, Eakin BL, Kazanis AS, McCullagh MC. Effects of booster interventions on factory workers' use of hearing protection. Nurs Res. 2004;53(1):53-8.

17. Sadler OW, Montgomery GM. The application of positive practice overcorrection to the use of hearing protection. Am Ind Hyg Assoc J. 1982;43(6):451-4.

18. Zohar D, Cohen A, Azar N. Promoting increased use of ear protectors in noise through information feedback. Hum Factors. 1980;22(1):69-79.

19. Davis RR, Sieber WK. Hearing protector use in noise-exposed workers: a retrospective look at 1983. AIHAJ (Fairfax, Va). 2002;63(2):199-204.

20. Ewigman BG, Kivlahan CH, Hosokawa MC, Horman D. Efficacy of an intervention to promote use of hearing protection devices by firefighters. Public Health Rep. 1990;105(1):53-9.

21. Roeser RJ, Coleman T, Adams RM. Implementing an industrial hearing conservation program in the schools. J Sch Health. 1983;53(7):408-11.

22. Toivonen M, Pääkkönen R, Savolainen S, Lehtomäki K. Noise attenuation and proper insertion of earplugs into ear canals. Ann Occup Hyg. 2002;46(6):527-30.

23. Walker JL. A successful program of hearing conservation for industry. IMS Ind Med Surg. 1972;41(2):11-4.

24. Williams W. Instruction and the improvement of hearing protector performance. Noise Health. 2004;7(25):41-7.

25. Knobloch MJ, Broste SK. A hearing conservation program for Wisconsin youth working in agriculture. J Sch Health. 1998;68(8):313-8.
26. Higgins JPT, Green S, editors. Cochrane Reviewers' Handbook 4.2.5. Assessment of study quality. Section 4 [updated May 2005]. In: The Cochrane Library, Issue 3, 2005. Chichester: John Wiley \& Sons, Ltd.; 2005.

27. Jüni P, Witschi A, Bloch R, Egger M. The hazards of scoring the quality of clinical trials for meta-analysis. JAMA. 1999;282(11):1054-60.

28. Killip S, Mahfoud Z, Pearce K. What is an intracluster correlation coefficient? Crucial concepts for primary care researchers. Ann Fam Med. 2004;2(3):204-8.

29. Schulte PA, Stephenson CM, Okun AH, Palassis J, Biddle E. Integrating occupational safety and health information into vocational and technical education and other workforce preparation programs. Am J Public Health. 2005;95(3):404-11.

30. Prince MM, Colligan MJ, Stephenson CM, Bischoff BJ. The contribution of focus groups in the evaluation of hearing conservation program (HCP) effectiveness. J Safety Res. 2004:35(1):91-106.

31. Svensson EB, Morata TC, Nylén P, Krieg EF, Johnson AC. Beliefs and attitudes among Swedish workers regarding the risk of hearing loss. Int J Audiol. 2004;43(10):585-93.

This article has already been published in the Cochrane Library: RP El Dib, J Verbeek, AN Atallah, RB Andriolo, BGO Soares. Interventions to promote the wearing of hearing protection. Cochrane Database of Systematic Reviews 2006, Issue 2.

Acknowledgements: We would like to thank the Cochrane Occupational Health Sector and the Cochrane Ear, Nose and Throat Disorders Group for their support. We would also like to thank Jenny Bellorini and Jos Verbeek for their advice and suggestions throughout this review.

Sources of funding: None

Conflict of interest: Not declared

Date of first submission: December 12, 2006

Last received: November 12, 2007

Accepted: November 14, 2007 
AUTHOR INFDRMATIDN

Regina Paolucci El Dib, MSc. Clinical Trial Research Coordinator from McMaster University, Canada. Speech and hearing pathologist, and PhD student in Internal and Therapeutic Medicine and Evidence-Based Medicine at Universidade Federal de São Paulo (Unifesp). MSc from Unifesp. Title of Specialist in Speech and hearing pathologist for Neurological Rehabilitation from Unifesp, São Paulo, Brazil.

Álvaro Nagib Atallah, MD, PhD. Full professor of EvidenceBased Medicine and Urgent Medicine and Director of the Brazilian Cochrane Center, Universidade Federal de São Paulo, São Paulo, Brazil.

Régis Bruni Andriolo. Postgraduate MSc student at Universidade Federal de São Paulo (Unifesp) and scientific research assistant at Brazilian Cochrane Center, Unifesp, São Paulo, Brazil.

Bernardo Garcia de Oliveira Soares, MD. Psychiatrist, Brazilian Cochrane Center, Universidade Federal de São Paulo, São Paulo, Brazil.

Jos H. Verbeek. Coordinator, Cochrane Occupational Health Field. Dept of Occupational Health Services Research.Finnish Institute of Occupational Health, Kuopio, Finland.

\section{Address for correspondence:}

Regina Paolucci El Dib

Rua Castro Alves, 815 - Apto. 31 - Aclimação

São Paulo (SP) - Brasil - CEP 01532-001

Tel. (+55 11) 3486-8202 - (+55 11) 5579-0469

$-(+5511) 9932-4515$

E-mail: re.lucci@terra.com.br

Copyright $\odot$ 2007, Associação Paulista de Medicina
Revisão sistemática sobre intervenções para promover o uso de protetores auriculares
CONTEXTO E OBJETIVO: Perda auditiva induzida por ruído pode apenas ser prevenida eliminando ou
diminuindo os níveis de exposição sonora. Quando a fonte do ruído não pode ser eliminada, trabalha-
dores devem utilizar os equipamentos de proteção auditiva. O objetivo foi sumarizar as evidências sobre
efetividade das intervenções para aumentar o uso de protetores auriculares entre trabalhadores expostos
a ruídos.

ESTRATÉGIA DE BUSCA: Estudos randomizados foram identificados por busca eletrônica na literatura médica até 2005. Os dados foram checados duplamente e inseridos no software Review Manager software, versão 4.2.5.

RESULTADO PRINCIPAL: Dois estudos foram encontrados. Uma intervenção padronizada por computador em relação ao risco de um trabalhador individual durou 30 minutos e não foi mais efetiva do que um vídeo fornecendo informações gerais entre os trabalhadores. Um segundo ensaio clínico randomizado avaliou os efeitos de um programa de prevenção auditiva de quatro anos em uma escola onde jovens trabalhavam nas fazendas de seus pais. O grupo de intervenção foi duas vezes mais provável de usar algum tipo de protetor auricular do que o grupo controle, que recebeu mínima intervenção.

CONCLUSÃO DOS REVISORES: Limitada evidência não demonstrou quando as intervenções padronizadas são mais ou menos efetivas do que intervenções gerais em trabalhadores, $80 \%$ deles já utilizavam o protetor auricular. Intervenções longas em escolas podem aumentar substancialmente o uso de protetores auriculares. Melhores intervenções para aumentar o uso de Equipamentos de Proteção Individual (EPIs) devem ser desenvolvidas e avaliadas com intuito de aumentar a prevenção de perda auditiva induzida por ruído em trabalhadores.

PALAVRAS-CHAVE: Dispositivos de proteção das orelhas. Perda auditiva provocada por ruído. Ruído ocupacional. Literatura de revisão. Metanálise. 